\title{
Interphase nucleolar organiser regions and survival in squamous cell carcinoma of the bronchus: a 10 year follow up study of 138 cases
}

\author{
D A R Boldy, J G Ayres, J Crocker, J A H Waterhouse, M Gilthorpe
}

\begin{abstract}
Background Good prognostic indicators for patients with squamous cell carcinoma of the lung would help to determine the most appropriate treatment for individual patients.

Methods A silver colloid technique that shows interphase nucleolar organiser regions (AgNORs) has been applied to representative paraffin sections from 138 cases of squamous cell carcinoma of the bronchus treated by surgical resection of the primary tumour at East Birmingham Hospital in 1977. Of the 138 patients, $23(17 \%)$ were alive 10 years after their operation.
\end{abstract}

Results The mean (SD) AgNOR count per cell was significantly higher for all grades of malignancy (well differentiated 10.5 (2.6), moderately differentiated 10.7 $(3 \cdot 2)$, and poorly differentiated $12 \cdot 7(4 \cdot 5))$ than for normal pseudostratified columnar epithelium from non-affected areas $(2 \cdot 3(0 \cdot 78))$. There was a trend for AgNOR counts to be higher in poorly differentiated tumours, but a wide range of AgNOR counts was observed in all histological grades. AgNOR counts did not predict clinical outcome, irrespective of the stage of the disease, and did not relate to DNA ploidy or the percentage of cells in the proliferation phase of the cell cycle. Nine of 47 patients $(19 \%)$ with tumours classified as DNA diploid and eight of 63 patients $(13 \%)$ with DNA aneuploid tumours were alive 10 years after operation. Principal component analysis identified the clinicopathological stage of disease as the variable best related to survival. The percentage of patients surviving 10 years was $30 \%$ for stage $I, 20 \%$ for stage II, $10 \%$ for stage IIIa, $9 \%$ for stage IIIb, and none for stage IV.

Conclusion The AgNOR technique is not of prognostic value in postoperative patients with squamous cell carcinoma of the bronchus.

Hospital, Birmingham B9 5ST

Institute of

Occupational Health,

University of

Birmingham, PO Box

363, Birmingham B15

5ST

J A H Waterhouse

M Gilthorpe

Reprint requests to:

Dr Boldy

Accepted 19 September 1991
The nucleolus is formed by the associa chromosomal regions known as nucleo ribosomal RNA genes. Their interphase counterparts are the fibrillar centres, and both these and the nucleolus are often abnormal in malignant cells. ${ }^{12}$ A simple silver colloid technique $^{3}$ has been used recently by pathologists to stain proteins associated with nucleolar organiser regions; in interphase cells at the light microscope level these areas appear as small black dots, known as AgNORs. Previous work has shown that higher AgNOR counts per cell nucleus are observed in malignant tissue than in benign tissue. ${ }^{4-6}$ In addition, AgNOR counts may relate to the degree of tumour differentiation in neuroblastomas ${ }^{7}$ and to markers of cell proliferation in nonHodgkin's lymphomas. ${ }^{8}$ It has been suggested that the AgNOR method may be of prognostic value in neuroblastomas, ${ }^{7}$ breast carcinomas, ${ }^{9}$ and renal cell carcinomas, ${ }^{10}$ and in spontaneous mast cell tumours in dogs, ${ }^{11}$ though apparently not in some other malignant diseases in man. ${ }^{12-15}$ Studies on malignant mesothelioma ${ }^{4}$ and small cell carcinoma of the bronchus ${ }^{6}$ have suggested that the AgNOR method may be of diagnostic value, but there have been no studies in relation to prognosis for pulmonary tumours.

This study was undertaken to determine whether the AgNOR counts obtained from routine histological sections of squamous cell bronchial carcinoma relates to the histological differentiation of the tumour and whether the AgNOR method might be useful as an indicator of postsurgical survival in this condition, which is still the most commonly fatal malignancy in the United Kingdom. ${ }^{16}$

\section{Methods}

SELECTION OF PATIENTS AND DEMOGRAPHIC DATA Patients treated by surgical resection of squamous cell carcinoma of the bronchus at East Birmingham Hospital in 1977 were identified. After consent had been obtained from the thoracic surgeons responsible for the care of the patients, further information was collected by examination of the hospital case notes and the West Midlands Regional Cancer Registry forms. The data collected included the age and sex of the patient and the type of operation performed; pathological TNM staging was undertaken independently by two of the authors, who used the recent UICC classification. ${ }^{17}$ Where there was disagreement, all available data were re-examined for a consensus opinion. The operation notes and the histopathological report forms were used to provide details concerning the completeness of tumour resection, which was classified as: (1) complete resection; (2) resection leaving microscopic disease (tumour present at the resection line on the specimens examined); and (3) resection leaving macroscopic disease (tumour left in 
chest at the end of the operation). The West Midlands Cancer Registry was contacted to provide data on the clinical outcome, including cause of death from the death certificate, for all patients. Deaths in the first 30 days after surgery were regarded as postoperative deaths and were not included in the subsequent analysis. Patients were classified as having died as a result of their tumour if such a diagnosis was mentioned in part I of the death certificate. The original haematoxylin and eosin slides were re-examined by one histopathologist (JC) to confirm the diagnosis of squamous cell carcinoma. One tumour was reclassified as a malignant haemangiopericytoma and was excluded from the study. If the quality of the original slides was regarded as poor, fresh sections were cut, stained, and examined. One section, which was representative of the tumour as a whole, was selected for further study and was classified as showing tumour that was well differentiated, moderately differentiated, or poorly differentiated. Areas of normal pseudostratified columnar epithelium were also identified where possible.

\section{AGNOR STAINING AND COUNTING}

Sections of $3 \mu \mathrm{m}$ were obtained from each paraffin block selected for histological classification and stained by our standard technique. ${ }^{18}$ Briefly, the sections were dewaxed in ethanols and taken to water. Gelatin dissolved in $1 \%$ formic acid to produce a $2 \%$ solution was mixed with $50 \%$ aqueous silver nitrate in a $1: 2$ ratio and immediately placed on the specimens. The sections were incubated for 35 minutes in safelight (Kodak 1A) conditions, washed in distilled deionised water, taken to xylene, and mounted in a synthetic medium. The number of cells to be counted was determined by the moving mean method, and 50 cells of defined type (tumour cells or normal epithelium) per specimen were counted as described previously, ${ }^{18}$ at a magnification of $\times 1000$ under oil immersion. To assess the reproducibility of the counting method, the first 20 specimens were recounted in random order after an interval of six months by the same investigator.

\section{DNA FLOW CYTOMETRY}

From the same paraffin block used for histological classification and AgNOR counting a $60 \mu \mathrm{m}$ section was cut and single cell suspensions were prepared by the method of Hedley and colleagues. ${ }^{19}$ The cells were stained with $0.05 \%$ propidium iodide solution in $0.1 \%$ sodium citrate with $1 \mathrm{mg} / \mathrm{ml}$ RNase ( $R$ 4875, Sigma Chemical Co, Poole). An equivalent amount of fixing buffer $(0.1 \%$ Triton-X 100 in phosphate buffered saline, containing $0.07 \%$ paraformaldehyde) was added. The samples were placed in ice until DNA flow cytometry was undertaken, a Becton-Dickinson FACS 440 being used with the argon laser set at an excitation wavelength of $480 \mathrm{~nm}$ and an emission wavelength of $560-650 \mathrm{~nm}$. At least 30000 events were counted. The coefficient of variation for the main $\mathrm{G} 0 / \mathrm{Gl}$ peak was calculated by means of integral software. Tumours were classified as DNA aneuploid if a discernible peak was visible that was separate from the main G0/G1 peak of normal cells or if the apparent G2M peak channel:G0/G1 peak channel ratio was greater than $1 \cdot 1$ or less than 0.9 . For tumours with a normal DNA content (DNA diploid) the percentage of proliferating cells was calculated by the method of Baisch et al. $^{20}$

\section{ANALYSIS}

Student's unpaired $t$ test was used to analyse differences in AgNOR counts between normal epithelium and tumour subgroups on the basis of histological differentiation, with $95 \%$ confidence intervals calculated by the method of Gardner and Altman. ${ }^{21}$ Wilcoxon's rank sum test for unpaired groups was used to determine whether the percentage of proliferating cells in diploid tumours related to prognosis. For univariate analysis with respect to the patients' survival the data were age adjusted ${ }^{22}$ and the log rank test was used to determine significance. ${ }^{23}$ Relationships between the various quantities were analysed by the use of correlation coefficients. Principal component analysis ${ }^{24}$ was used from the correlation matrix to produce, as new factors, several linear combinations (eigenvectors) of these quantities such that they account for, in descending order, fractions of the overall original variability.

Table 1 Data for 138 patients with squamous cell carcinoma of the bronchus treated by surgical resection in 1977

\begin{tabular}{ll}
\hline $\begin{array}{l}\text { Age (y): mean (SD) } \\
\text { range }\end{array}$ & $60 \cdot 6(6 \cdot 6)$ \\
& $40-73$ \\
Male & $N o(\%)$ \\
Female & $124(89 \cdot 9)$ \\
Lobectomy & $14(10 \cdot 1)$ \\
Pneumonectomy & $79(57 \cdot 2)$ \\
Stage I & $56(40 \cdot 6)$ \\
$\quad$ II & $47(34 \cdot 1)$ \\
$\quad$ IIIA & $49(35 \cdot 5)$ \\
$\quad$ IIIB & $27(19 \cdot 6)$ \\
IV & $11(8 \cdot 0)$ \\
DNA diploid & $4(2 \cdot 9)$ \\
DNA aneuploid & $47(42 \cdot 7)$ \\
\end{tabular}

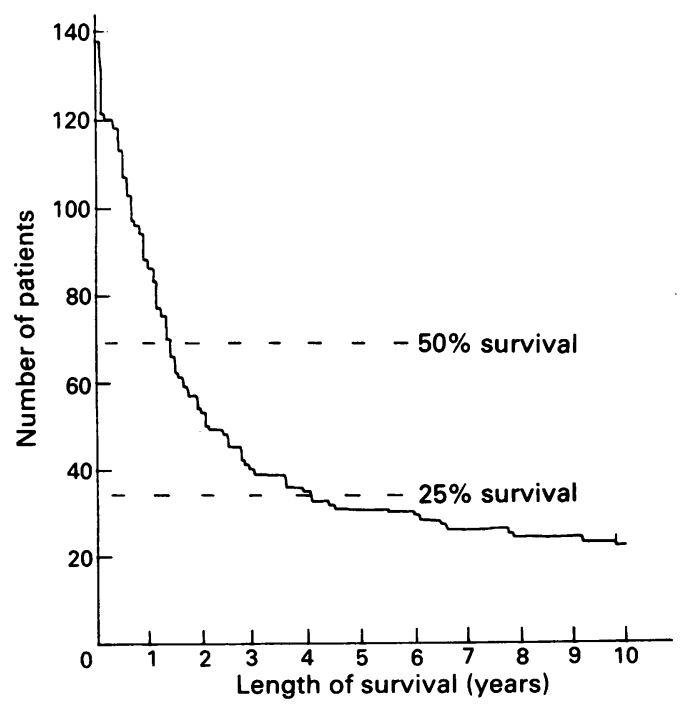

Figure 1 Survival of 138 patients with squamous cell carcinoma of the bronchus treated by surgical resection in 1977. 


\section{Results}

The demographic data are summarised in table 1. Of the 138 patients undergoing surgical resection, 17 died in the first 30 days after surgery. Follow up was complete, apart from one patient who was lost to follow up after 110 months; $33(27 \%)$ patients were alive at five

Figure 2 Factors with a significant effect on survival (postoperative deaths excluded) in 138 patients with squamous cell carcinoma of the bronchus treated by surgical resection in 1977: $A$ stage of disease; $B$-extent of tumour resection; $C$ operation performed.
Figure 3 Factors with no observed effect on survival (postoperative deaths excluded) in 138 patients with squamous cell carcinoma of the bronchus treated by surgical resection in 1977: $A$ histological differentiation; $B-D N A$ ploidy.
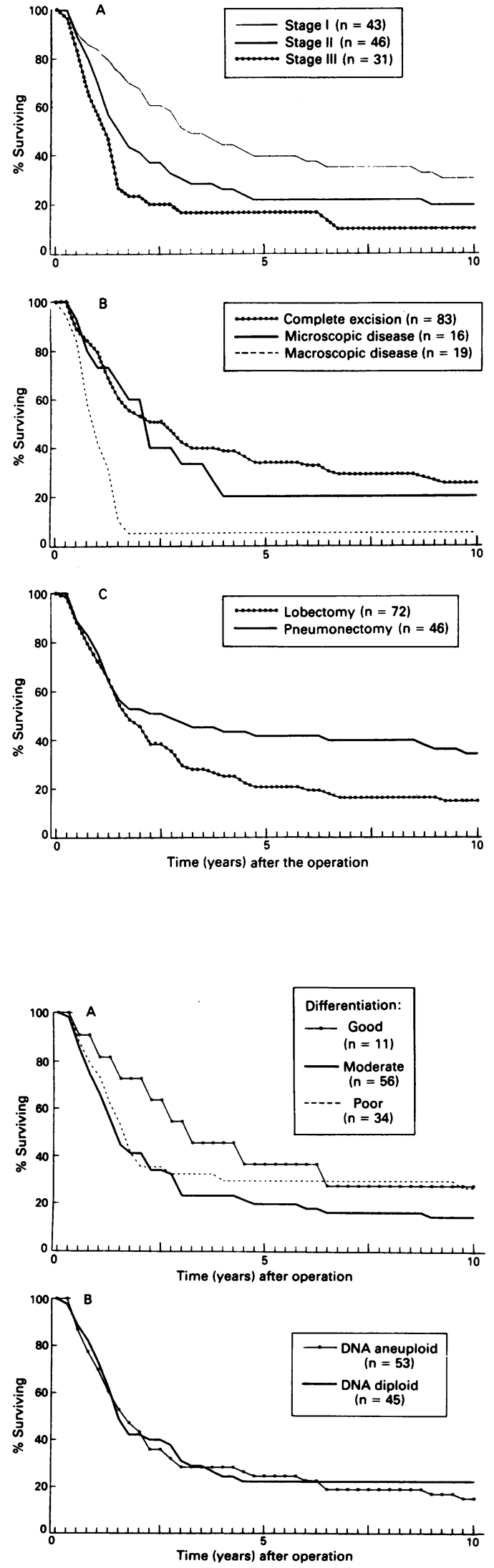

years and $23(17 \%)$ were alive at 10 years (fig 1 ). Of the 99 deaths during the follow up period, carcinoma of the bronchus was reported as the main cause of death in 85 patients. A good prognosis was associated with a lower disease stage $\left(\chi^{2}=9 \cdot 7, \mathrm{df}=3, \mathrm{p}<0.025\right.$ at 10 years; fig $2 \mathrm{~A})$, complete resection of the tumour $\left(\chi^{2}=\right.$ 15.5 , df $=2, p<0.001$ at 10 years; fig $2 B$ ), and pneumonectomy rather than lobectomy $\left(\chi^{2}=4 \cdot 1, \mathrm{df}=2, \mathrm{p}<0.05\right.$ at 10 years, fig $\left.2 \mathrm{C}\right)$. The degree of histological differentiation (fig 3A) and DNA ploidy (fig 3B) did not relate to outcome. For DNA diploid tumours with less than $10 \%$ of cells in the proliferating phase the median survival was 32 months compared with 15.5 months for tumours with $10 \%$ or more of proliferating cells $(Z=2 \cdot 14, p<0.02)$.

Good AgNOR staining was produced in all but 10 cases; in these specimens we could not produce an adequate stain despite at least six attempts.

Eleven areas of normal pseudostratified columnar epithelium were also identified. The results of the AgNOR counts for the 117 specimens that could be classified into one histological group are shown in figure 4, higher AgNOR counts being observed in all tumour subgroups than in normal epithelium ( $p<$ 0.0001). Although AgNOR numbers tended to be higher in the less well differentiated tumours (well differentiated (mean (95\% confidence

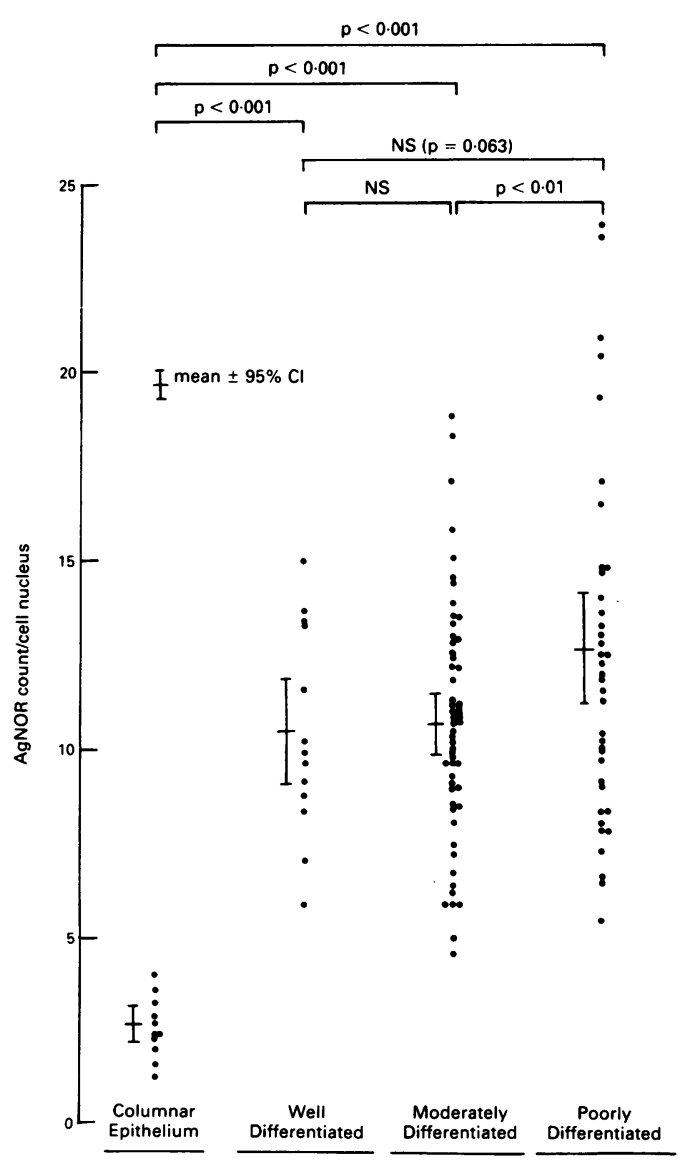

Figure 4 Mean AgNOR counts per cell nucleus in normal pseudostratified columnar epithelium $(n=11)$ and in well differentiated $(n=13)$, moderately differentiated $(n=56)$, and poorly differentiated $(n=38)$ squamous cell carcinoma of the bronchus. 


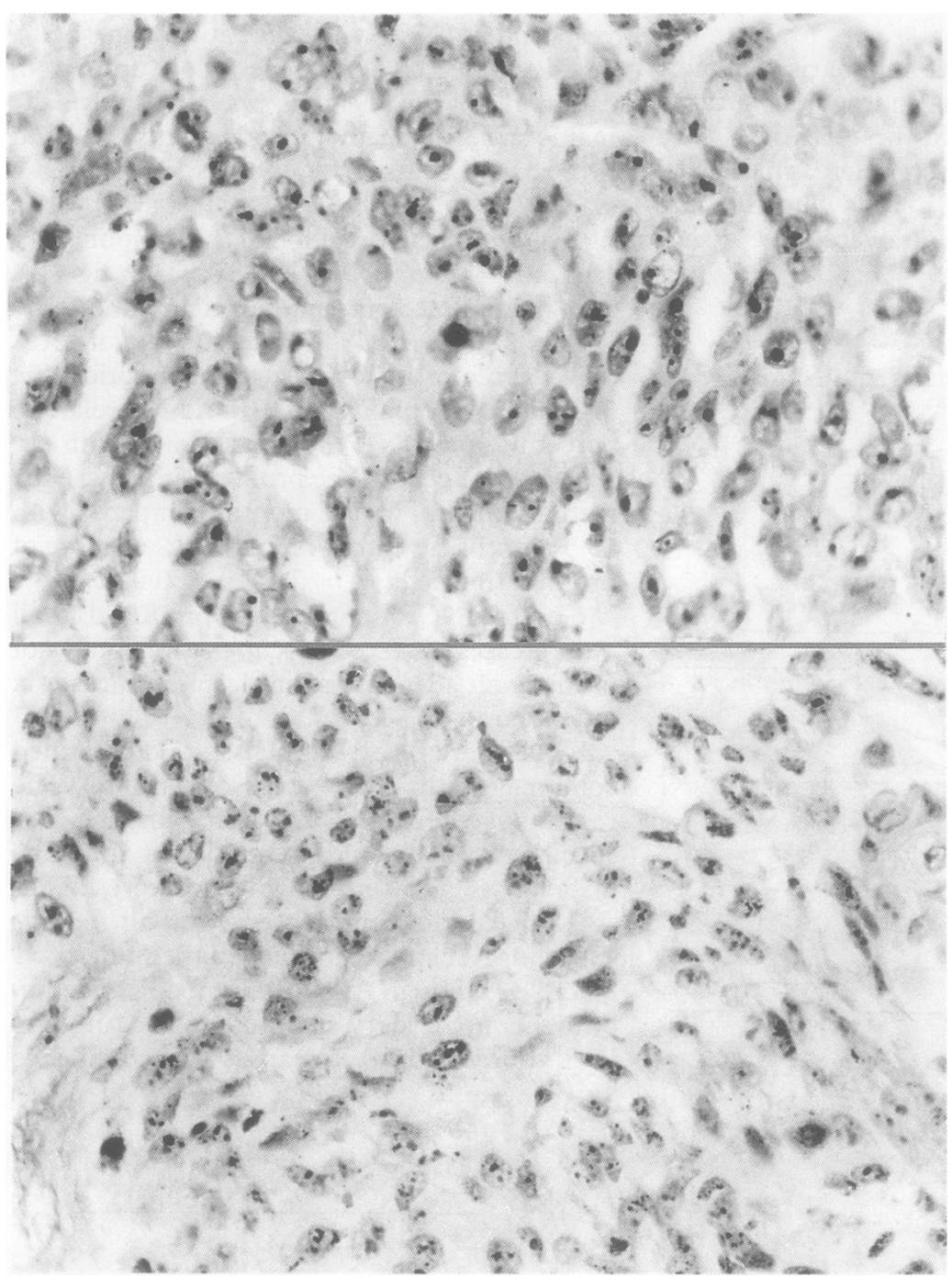

Figure 5 Squamous cell carcinoma of the bronchus stained by the AgNOR silver staining method: $A-A g N O R s$ aggregated into nucleolar structures; $B-A g N O R s$ dispersed throughout the nucleus. interval) $10 \cdot 5(8 \cdot 9-12 \cdot 1)$, moderately differentiated $10 \cdot 7(9 \cdot 9-11 \cdot 5)$, and poorly differentiated $12 \cdot 7(11 \cdot 3-14 \cdot 1))$, the range of AgNOR scores in each histological subgroup was wide and there was considerable overlap between the groups (fig 4). Higher scores were associated with AgNOR dots scattered throughout the nucleus rather than concentrated in obvious nucleoli (figs 5A and 5B). Repeat counting of 20 specimens after an interval of six months showed that there was good agreement between the two counts (mean difference $+0 \cdot 29$, coefficient of variation $11 \cdot 1 \%$ ), and that the difference between the two counts was not related to the mean number of AgNORs for the two counts (fig 6). AgNOR scores were not related to survival in the group as a whole (fig 7). When patients were subdivided by stage of disease there was no correlation between the AgNOR count and survival, even for patients with stage I disease and apparently complete removal of the tumour (fig 8). AgNOR counts were similar in DNA diploid (mean (SD) count $11.4(3.8)$ ) and DNA aneuploid (11.2(3.4)) tumours. For DNA diploid tumours there was no correlation between AgNOR score and the percentage of proliferating cells $(r=0 \cdot 108)$.

The eigenvectors obtained from the correlation matrix are shown in table 2 , in descending order of proportional variance. These vectors are nearly equal contributors to the total variance and account for over $60 \%$ of it. They indicate the grouping of factors causing the variance and their interrelations. In vector 2 (which accounts for $21.3 \%$ of the original variance) the weightings for survival $(-0.588)$ and for stage of disease $(0.598)$ are substantial. These two weights are the highest of all (except that for age in vector 3 ), and show that survival is linked most closely with disease stage (the higher the stage the shorter the survival).

\section{Discussion}

Carcinoma of the bronchus remains the major cause of death from malignant disease in the United Kingdom. ${ }^{16}$ For most patients with non-small cell carcinoma of the bronchus surgical resection offers the greatest possibility of cure. ${ }^{25}{ }^{26}$ Even in reported series the five year survival is only $24 \cdot 5-32 \% .^{26-28}$ Indicators of prognosis are much sought after to improve clinical practice by enabling doctors to decide on the most appropriate treatment. For bronchial carcinoma accurate tumour staging at the time of diagnosis is a powerful indicator of prognosis, though this may be affected by the histological type of tumour. ${ }^{27}$ To remove the effect of histological cell type from this study we deliberately studied only squamous cell carcinomas. More recently, it has been suggested that DNA ploidy is also an important prognostic indicator in non-small cell carcinoma of the bronchus. ${ }^{29} 30$ This study confirms the value of accurate p-TNM staging as a prognostic indicator for squamous cell carcinoma of the bronchus, but failed to show that DNA flow cytometry was useful in this context. Even for stage I tumours in this series no relationship could be detected, a finding also reported by van Bodegam and colleagues. ${ }^{31}$ A possible explanation for this is that suggested by Carey and coworkers, ${ }^{32}$ who have shown that examination
Figure 6 AgNOR counts in squamous cell carcinoma of the bronchus: repeatability of the counting technique, expressed as the absolute difference between two counts compared with the mean of each pair of counts $(n=20)$

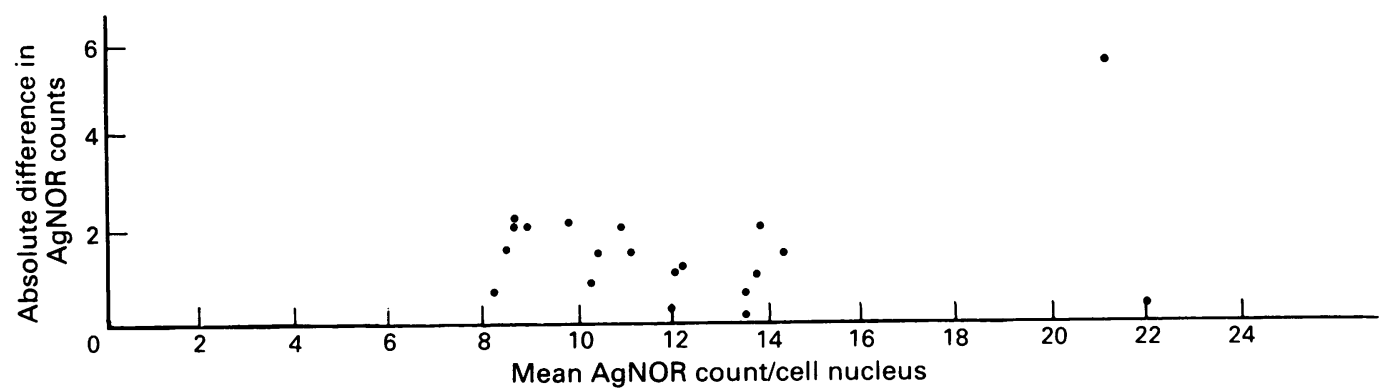




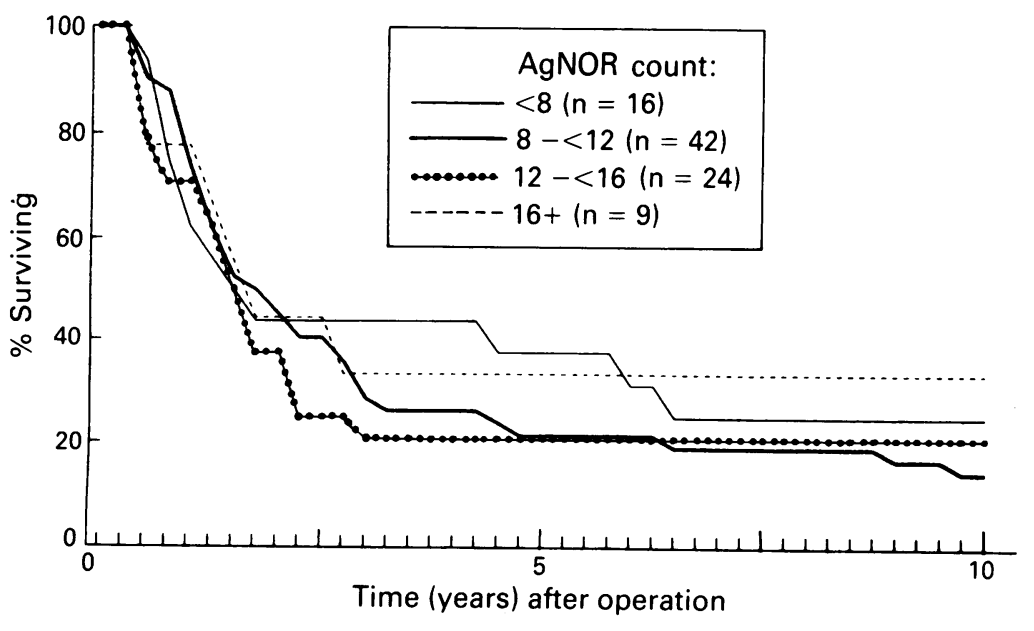

Figure 7 AgNOR counts and survival (excluding postoperative deaths) in 138 patients with squamous cell carcinoma of the bronchus treated by surgical excision in 1977. the stain by virtue of their carboxyl and sulphydryl groups. The DNA of these regions is transcribed into the $45 S$ rRNA, which is split subsequently into the $18 S$ and $28 S$ subunits constituting the major components of the ribosomes. The function of the NOR associated proteins is uncertain, but it is thought that they may regulate transcription of rDNA and thereby reflect nuclear and cellular activity. This study again confirms that AgNOR counts are much higher in malignant tissue than in benign tissue. ${ }^{45}$ In addition, there was a trend for higher AgNOR counts to be observed in more poorly differentiated tumours, a finding similar to that reported by Egan and colleagues for cervical intraepithelial neoplasia. ${ }^{33}$

The higher AgNOR counts reflect, in the main, wide dispersal of the AgNOR dots throughout the nucleus, rather than a large number associated together in the nucleolus, in keeping with the report for breast carcinomas. ${ }^{9}$ There are several possible causes for the raised AgNOR counts in interphase cells. Firstly, an overall increase in chromosomal numbers might produce an increase in NOR bearing chromosomes and thus interphase AgNORs; a cytogenetic and histopathological study of 13 patients with non-Hodgkin's lymphoma, however, showed no consistent relation between these two. ${ }^{34}$ DNA ploidy is an indirect measure of total chromosomal DNA and we, like other workers, ${ }^{15}$ did not observe higher AgNOR counts in aneuploid than in diploid tumours. A second possibility is that the number of discernible AgNORs may increase in the premitotic and postmitotic phases of the cell cycle as the chromosomes disaggregate and reorganise, an increase in AgNOR numbers thus reflecting an increase in cell turnover or proliferation. Sequential staining has confirmed that higher AgNOR counts are found in pro-
Figure 8 AgNOR counts and survival in patients with stage I squamous cell carcinoma of the bronchus and total clearance of the tumour by surgery $(n=30)$.

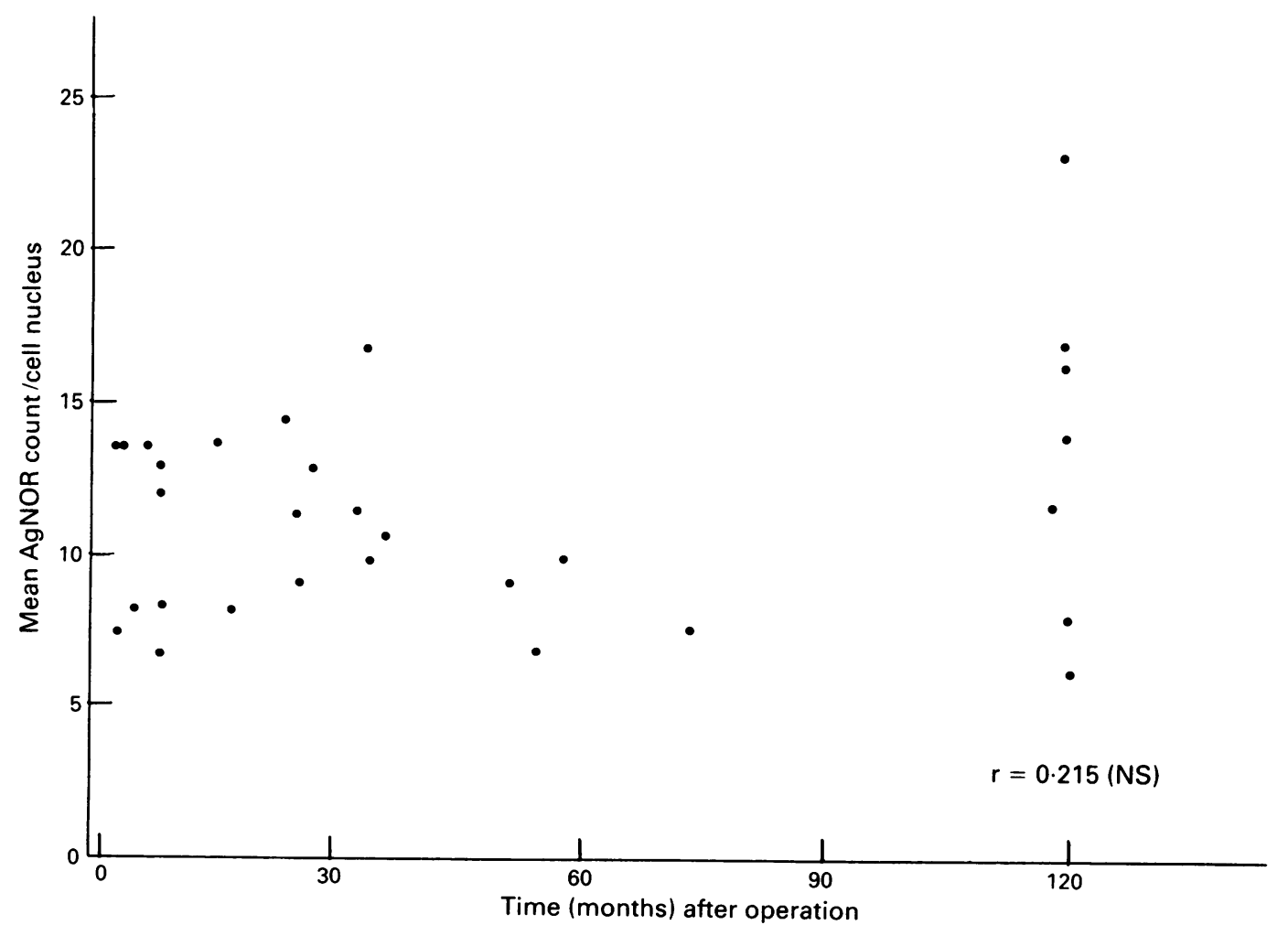


Table 2 Eigenvectors and proportion of original variance for 138 patients with squamous cell carcinoma of the bronchus treated by surgical resection in 1977

\begin{tabular}{|c|c|c|c|}
\hline & \multicolumn{3}{|l|}{ Vector } \\
\hline & 1 & 2 & 3 \\
\hline Length of survival & 0.086 & -0.588 & -0.352 \\
\hline Age of patient & 0.416 & 0.039 & -0.612 \\
\hline Stage of disease & -0.234 & 0.598 & 0.025 \\
\hline Histological subgroup & 0.564 & $0 \cdot 188$ & 0.412 \\
\hline AgNOR count & 0.464 & -0.290 & -0.470 \\
\hline DNA ploidy & 0.482 & 0.420 & -0.331 \\
\hline $\begin{array}{l}\text { Proportion of } \\
\text { original variance }\end{array}$ & $0 \cdot 220$ & 0.213 & $0 \cdot 194$ \\
\hline
\end{tabular}

liferating cells than in cells in the resting phase of the cell cycle. ${ }^{35}$ A strong correlation has been observed between AgNOR counts and the mitosis-karyorrhexis index for neuroblastomas $^{7}$ but not for breast carcinomas. ${ }^{36}$ Other markers of cell proliferation, such as $\mathrm{Ki} 67$ and the percentage of $S$ phase cells, correlate well with AgNOR counts in non-Hodgkin's lymphoma ${ }^{87}$ but not in other tumours, such as carcinomas of the breast ${ }^{38}$ and rectum. ${ }^{15}$ There was no correlation between proliferating cells and AgNOR counts in this study, but AgNOR counts may be affected by the presence of inflammatory cells, which are also examined by DNA flow cytometry. A third possibility is that AgNOR counts reflect the degree of cellular differentiation. ${ }^{39}$ When promonocytic U937 cells were incubated with each of three different inducing agents the AgNOR scores were reduced. ${ }^{39}$ When the cytokines were removed from the culture AgNOR scores increased again as the cells returned to their undifferentiated state. Fourthly, the increased AgNOR count might reflect an increase in transcriptional activity. The final possibility is a defect in nucleolar organisation, ${ }^{40}$ resulting in nucleolar disorganisation. Neither of these last two possibilities can be examined from the present data.

Our study did not show any association between the mean AgNOR count and survival, irrespective of the stage of the disease or the completeness of resection; this suggests that AgNOR counts throw no light on the prognosis after surgery in squamous cell carcinoma of the bronchus. There have been three studies with small numbers of patients, on embryonal rhabdomyosarcoma, ${ }^{12}$ Ewing's sarcoma of childhood, ${ }^{13}$ and thick cutaneous malignant melanoma, ${ }^{14}$ and one large study of 100 patients with rectal adenocarcinoma, ${ }^{15}$ in which no association was found between AgNOR counts and survival. In contrast, the AgNOR count was related to prognosis in a study of 20 neuroblastomas, though no data were included on therapeutic interventions. ${ }^{7}$ In mast cell tumours in dogs treated by complete excision of the primary growth the AgNOR count was a good predictor of whether the tumour would recur, though little better than the histological grade of the tumour or the mitotic index. ${ }^{11} \mathrm{~A}$ large study of 182 cases of renal cell carcinoma has shown that the AgNOR count was a significant predictor of survival, independent of the stage of the tumour. ${ }^{10}$ Thus there is still doubt about the value of the AgNOR count as a prognostic indicator and further studies are required on large series of patients to help to define the role of this technique in histopathological practice.

This work was supported in part by a grant from the Chest, Heart, and Stroke Association.

Koller PC. The nucleus of the cancer cell-a historical review. Exp Cell Res 1963;9:3-14.

2 Busch H, Smetana K. Nucleoli of tumour cells. In: Busch H, Smetana K, eds. The nucleolus. New York: Academic Press, 1970:448-71.

3 Ploton D, Menager M, Jeannesson P, Himber G, Pigeon F, Adnet JJ. Improvement of staining and in visualisation of the argyrophilic proteins of the nucleolar organise regions at the optical level. Histochem $J$ 1986;18:5-14.

4 Ayres JG, Crocker J, Skilbeck NQ. Differentiation of malignant from normal and reactive mesothelial cells by the argyrophil technique for nucleolar organiser region associated proteins. Thorax 1988;43:366-70.

5 Crocker J, Skilbeck N. Nucleolar organiser region associated proteins in cutaneous melanotic lesions: a quantiative study. J Clin Pathol 1987;40:885-9.

6 Crocker J, Ayres JG, McGovern J. Nucleolar organiser regions in small cell carcinoma of the bronchus. Thorax 1987;42:972-5.

7 Egan M, Raafat F, Crocker J, Williams D. Comparative study of the degree of differentiation of neuroblastoma and mean numbers of nucleolar organiser regions. J Clin Pathol 1988;41:527-31.

8 Hall PA, Crocker J, Watts A, Stansfeld AG. A comparison of nucleolar organiser region staining and $\mathrm{Ki}-67$ immunostaining in non-Hodgkin's lymphoma. Histopathology 1988;12:373-81.

9 Sivridis E, Sims B. Nucleolar organiser regions: new prognostic variable in breast carcinomas. J Clin Pathol 1990; 43:390-2.

10 Delahunt B, Ribas JL, Nacey JN, Bethwaite PB. Nucleolar organizer regions and prognosis in renal cell carcinoma. $J$ Pathol 1991;163:31-7.

11 Bostock DE, Crocker J, Harris K, Smith P. Nucleolar organiser regions as indicators of post-surgical prognosis in canine spontaneous mast cell tumours. $\mathrm{Br} J$ Cancer 1989;59:915-8.

12 Egan MJ, Raafat F, Crocker J, Williams D. Prognostic importance of nucleolar organiser regions in embryonal rhabdomyosarcoma [letter]. J Clin Pathol 1988;41:477.

13 Egan MJ, Raafat F, Crocker J, Williams D. Prognostic importance of nucleolar organiser regions in Ewing's sarcoma of childhood [letter]. J Clin Pathol 1988;41:232.

14 Howat AJ, Giri DD, Wright AL, Underwood JCE. Silverstained nucleoli and nucleolar organiser region counts are of no prognostic value in thick cutaneous malignant melanoma. $J$ Pathol 1988;156:227-32.

15 Griffiths AP, Butler CW, Roberts P, Dixon MF, Quirke P. Silver-stained structure (AgNORs), their dependence on tissue fixation and absence of prognostic relevance in rectal adenocarcinoma. J Pathol 1989;159:121-7.

16 Office of Population Censuses and Surveys. Deaths by cause: June quarter 1989 registrations. OPCS Monitor 1989; DH2 89/4:2-3.

17 International Union Against Cancer. TNM classification of malignant tumours 2nd ed. Geneva: Springer, 1987:69-73.

18 Crocker J, Nar P. Nucleolar organizer regions in lymphomas. J Pathol 1987;151:111-8.

19 Hedley DW, Friedlander ML, Taylor IW, Rugg CA, Musgrove EA. Method for analysis of cellular DNA content of paraffin-embedded pathological material using content of paraffin-embedded pathological material using

20 Baisch H, Gohde W, Linden WA. Analysis of PCP-data to determine the fractions of cells in the various phases of cell cycle. Radiat Environ Biophys 1975;12:31-9.

21 Gardner MJ, Altman DG. Confidence intervals rather than $p$ values: estimation rather than hypothesis testing. BMJ values: estimation

22 Office of Population Censuses and Surveys. English Life Tables No 14 (1980-!982). London: HMSO, 1987.

23 Peto R, Pike MC, Armitage P, Breslow NE, Cox DR Howard SV, et al. Design and analysis of randomised clinical trials requiring prolonged observation of each patient. II. Analysis and examples. Br J Cancer 1977;35 1-39.

24 Chatfield $\mathrm{C}$ Collins $\mathrm{AJ}$. Introduction to multivariate analys London: Chapman and Hall, 1980:57-81.

25 Stanford W, Spivey CG, Larsen GL, Alexander JA, Besich WJ. Results of treatment of primary carcinoma of the lung. Analysis of 3000 cases. J Thorac Cardiovasc Surg 1976;72:441-9.

26 Edinburgh Lung Cancer Group. Patients presenting with lung cancer in South East Scotland. Thorax 1987;42: 853-7. 
27 Mountain CF. Assessment of the role of surgery for control of lung cancer. Ann Thorac Surg 1977;24:365-71.

28 Ashraf MH, Milsom PL, Walesby RK. Selection by mediastinoscopy and long-term survival in bronchial carcinoma. Ann Thorac Surg 1980;30:208-14.

29 Volm M, Mattern J, Sonka J, Vogt-Schaden M, Wayss K DNA distribution in non-small-cell lung carcinomas and its relationship to clinical behaviour. Cytometry 1985; 6:348-56.

30 Zimmerman PV, Bint MH, Hawson GAT, Parsons PG. Ploidy as a prognostic determinant in surgically treated lung cancer. Lancet 1987;ii:530-3.

31 Van Bodegam PC, Baak JPA, Stroet-van Galen C, Schipper NW, Wisse-Brekelmans ECM, Vanderschueren RGJRA et al. The percentage of aneuploid cells is significantly correlated with survival in accurately staged patients with stage I resected squamous cell lung cancer and long-term follow up. Cancer 1989;63:143-7.

32 Carey FC, Lamb D, Bird CC. Intratumoral heterogeneity of DNA content in lung cancer. Cancer 1990;65:2266-9.

33 Egan $M$, Freeth $M$, Crocker J. Intraepithelial neoplasia, human papilloma virus infection and argyrophilic
nucleoprotein in cervical epithelium. Histopathology 1988; nucleopro

34 Jan-Mohamed RM, Armstrong SJ, Crocker J, Leyland MJ,
Hulten MA. The relationship between number of interphase NORs and NOR-bearing chromosomes in nonHodgkin's lymphoma. J Pathol 1989;158:3-7.

35 Janmohamed RMI, Murray PG, Crocker J, Leyland MJ. Sequential demonstration of nucleolar organizer regions and $\mathrm{Ki} 67$ immunolabelling in non-Hodgkin's lymphomas. Clin Lab Haemat 1990;12:395-9.

36 Smith R, Crocker J. Evaluation of nucleolar organizer region-associated proteins in breast malignancy. Histopathology 1988;12:113-25.

37 Crocker J, Macartney JC, Smith PJ. Correlation between DNA flow cytometric and nucleolar organizer region data in non-Hodgkin's lymphomas. $J$ Pathol 1988;154:151-6.

38 Giri DD, Nottingham JF, Lawry J, Dundas SAC, Underwood JCE. Silver-binding nucleolar organizer regions (AgNORs) in benign and malignant breast lesions: correlations with ploidy and growth phase by DNA flow relations with ploidy and growth phase

39 Edwards S, Afford S, Crocker J. The effect of inducing agents on the numbers of interphase fibrillar centers in the U937 promonocytic cell line. Exp Cell Res 1991;194:118-21.

40 Underwood JCE, Giri DD. Nucleolar organizer regions as diagnostic discriminants for malignancy [editorial]. $J$ Pathol 1988;155:95-6. 